\title{
Universiteit
}

Leiden

The Netherlands

\section{Relating academics' ways of integrating research and teaching to their students' perceptions}

Visser, G.J.; Driel, J.H. van; Rijst, R.M. van der; Visser, A.; Verloop, N.; Visser, A; Verloop, $\mathrm{N}$

\section{Citation}

Visser, G. J., Driel, J. H. van, Rijst, R. M. van der, Visser, A., \& Verloop, N.

(2012). Relating academics' ways of integrating research and teaching to their students' perceptions. Studies In Higher Education, 37(2), 219-234.

doi:10.1080/03075079.2010.536913

Version: $\quad$ Not Applicable (or Unknown)

License: $\quad$ Leiden University Non-exclusive license

Downloaded from: $\quad \underline{\text { https://hdl.handle.net/1887/24543 }}$

Note: To cite this publication please use the final published version (if applicable). 
This article was downloaded by: [Universiteit Leiden / LUMC ]

On: 09 March 2012, At: 01:25

Publisher: Routledge

Informa Ltd Registered in England and Wales Registered Number: 1072954 Registered

office: Mortimer House, 37-41 Mortimer Street, London W1T 3J H, UK

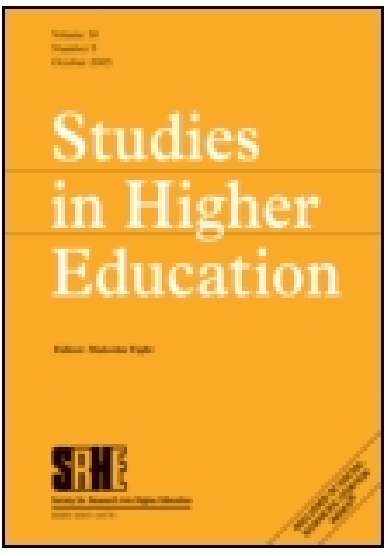

\section{Studies in Higher Education}

Publication details, including instructions for authors and subscription information:

http:// www.tandfonline.com/loi/ cshe20

\section{Relating academics' ways of integrating research and teaching to their students' perceptions}

Gerda J. Visser-Wijnveen ${ }^{a}$, J an H. van Driel ${ }^{a}$, Roeland M. van der Rijst ${ }^{a}$, Anthonya Visser ${ }^{b} \&$ Nico Verloop ${ }^{a}$

a ICLON Graduate School of Teaching, Leiden University, P.O. Box 905, 2300, AX, Leiden, The Netherlands

${ }^{b}$ Faculty of Humanities, Leiden University, Leiden, The Netherlands

Available online: 24 May 2011

To cite this article: Gerda J. Visser-Wijnveen, Jan H. van Driel, Roeland M. van der Rijst, Anthonya Visser \& Nico Verloop (2012): Relating academics' ways of integrating research and teaching to their students' perceptions, Studies in Higher Education, 37:2, 219-234

To link to this article: http:// dx.doi.org/ 10.1080/ 03075079.2010.536913

\section{PLEASE SCROLL DOWN FOR ARTICLE}

Full terms and conditions of use: http://www.tandfonline.com/page/terms-andconditions

This article may be used for research, teaching, and private study purposes. Any substantial or systematic reproduction, redistribution, reselling, loan, sub-licensing, systematic supply, or distribution in any form to anyone is expressly forbidden.

The publisher does not give any warranty express or implied or make any representation that the contents will be complete or accurate or up to date. The accuracy of any instructions, formulae, and drug doses should be independently verified with primary sources. The publisher shall not be liable for any loss, actions, claims, proceedings, demand, or costs or damages whatsoever or howsoever caused arising directly or indirectly in connection with or arising out of the use of this material. 


\title{
Relating academics' ways of integrating research and teaching to their students' perceptions
}

Gerda J. Visser-Wijnveen ${ }^{\mathrm{a} *}$, Jan H. van Driel ${ }^{\mathrm{a}}$, Roeland M. van der Rijst ${ }^{\mathrm{a}}$, Anthonya Visser $^{\mathrm{b}}$ and Nico Verloop ${ }^{\mathrm{a}}$

${ }^{a}$ ICLON Graduate School of Teaching, Leiden University, P.O. Box 905, 2300 AX Leiden, The Netherlands; ${ }^{b}$ Faculty of Humanities, Leiden University, Leiden, The Netherlands

\begin{abstract}
A wide variety of studies has been carried out regarding the way academics view the research-teaching nexus, while other studies have focused on the students' experience of research-intensive environments. This study links these two research streams, and describes how 12 staff members in a faculty of humanities integrate research into their teaching, and how their students perceive these learning environments. Data were gathered from both teachers and students. The 12 teachers opted for different ways of integrating disciplinary research into their teaching. The study produced some unexpected benefits, as the attained learning environment yielded more and other outcomes than intended. It was possible to attribute dispositional learning outcomes to students bringing the academic disposition into practice, and discussing their efforts with their teachers, while awareness of research increased as a result of getting a close look at the teacher's own research.
\end{abstract}

Keywords: academic disposition; learning environment; research awareness; research-teaching nexus; student learning

\section{Introduction}

The wish to link research and teaching is articulated especially in research universities, although a strong symbiosis is not easily achieved (Boyer Commission 1998). Zubrick, Reid, and Rossiter (2001) give several reasons for strengthening this nexus. Shifting contexts and expectations lead to uncertainties for universities as organisations and for individual academics. An emphasis on the link between research and teaching stimulates teachers and students to develop a culture of critical enquiry. Other reasons include the wish to retain one's status in the competitive field of higher education, to value and reward the diversity of academic work, to improve the quality of both university teaching and research, and to raise the status of teaching as compared to research. Only the first reason affects the students directly, with all others primarily related to academics or the university as a whole. In this article we would like to draw attention to both teacher and student perspectives on the connection between research and teaching, and are especially interested in the relationship between them. We will first pay attention to academics' experiences and views, and then turn to students' experiences regarding the research-teaching nexus.

\footnotetext{
*Corresponding author. Email gjvisser@iclon.leidenuniv.nl
} 


\section{Academic perspective}

On the basis of interviews with academics, the studies of Robertson and Bond (2001) and Coate, Barnett, and Williams (2001) report different experiences of the relationship between research and teaching. The first study describes a variety of relationships between research and teaching, ranging from mutually incompatible activities to sharing a symbiotic relationship within a learning community (Robertson and Bond 2001). The ends of this range coincide with the categories 'independent' and 'integrated' found by Coate, Barnett, and Williams (2001). Furthermore, they added the categories 'negative impact' and 'positive impact' (of research to teaching, and vice versa). Negative influences are related to the higher value assigned to research over teaching. This creates an imbalance not only for some academics, but potentially also for educational programmes, because of conflicts of interest and time. On the other hand, research might improve teaching, because researchers teach from personal experience rather than second-hand knowledge.

\section{Goals}

Elen and Verburgh (2008) identified that academics at research-intensive universities perceive the linking of research and teaching as beneficial for students. A close connection is expected to result in a specific state of mind. A key element of this state of mind is a critical orientation. The link between research and teaching is fundamentally based on and directed towards a mature epistemological disposition (Elen, Lindblom-Ylänne, and Clement, 2007). This mature epistemological disposition includes not only critical thinking, but also curiosity and a willingness to take a stance and defend it with reasonable arguments (Elen and Verburgh 2008). The idea of a mature epistemological disposition resembles the 'scientific research disposition' investigated by van der Rijst (2009) amongst university science teachers. He distinguished six aspects of this disposition, namely an inclination to achieve, to be critical, to be innovative, to know, to share and to understand. A study among historians also indicated the importance of an academic disposition. McLean and Barker (2004) showed that university history lecturers agree that becoming a practising historian is far more desirable than just acquiring transferable skills. In contrast to the acquirement of skills, acquiring an academic disposition, such as to be able to form autonomous, well-informed, critical opinions about historians' debates, is an integral part of becoming a historian. Research activity is seen as extremely helpful to pursue this goal. So, linking research and teaching aims at a range of outcomes in the students, but is mostly directed towards their dispositions.

\section{Learning environment}

A wide variety of learning environments, in which academics purposefully integrate research into their teaching, has been identified in the literature. Many studies report some form of inquiry learning. This might entail either research projects in teams, or projects in which individual students carry out and discuss related research activities (Badley 2002; Colbeck 1998). In these cases students pursuing research is the primary means of learning. Another perspective is that of academics bringing their research into their teaching and the general curriculum (Durning and Jenkins 2005; Neumann 1992). Other variations are classes focusing mainly on the development of research 
skills, including modules in which only research methods are taught (Durning and Jenkins 2005).

Several authors mention the student level as a serious influence on the potential relationships; at graduate level the ties are usually closer than at undergraduate level (Durning and Jenkins 2005; Neumann 1992; Smeby 1998; Zamorski 2002). However, on the basis of observations, Colbeck (1998) found that the purpose of teaching - i.e. classroom instruction or training students to conduct research - was far more influential. Additionally, the discipline is important. In undergraduate education in the social sciences and humanities the link is easier to realise, as the degree of specialisation and the rate of knowledge development are lower than in the natural sciences (Smeby 1998). A last factor that academics consider relevant is class size (Shore, Pinker, and Bates 1990). This affects a preference for lecturing versus more interactive ways of teaching in larger groups, and therefore also implies different possibilities for integrating research and teaching.

\section{Student perspective}

Besides the studies on what academics do to enhance the research-teaching nexus, and the advantages and disadvantages they perceive or aim for, several authors have paid attention to how students experience research-intensive environments (Jenkins et al. 2003; Robertson and Blackler 2006; van der Rijst et al. 2009). Jenkins et al. (1998) stressed that the students' voices were missing in the debate. In recent years the students' voices have come to be heard, although in most studies the focus has been only on final-year undergraduates. Hence, the advantages and disadvantages that students report in these studies should be read from that perspective. Among the factors influencing how students perceive the link between research and teaching are the nature and level of the discipline, type and purpose of a course, the ability and motivation of the student, and the opportunity for personal interaction with teachers (Neumann 1994). Breen and Lindsay (1999) point towards student motivation: those who most appreciate research involvement are the intrinsically motivated students, while qualification-motivated students are indifferent to research activities, and the achievement-oriented students approach research negatively. We will discuss both the disadvantages and advantages perceived by the students as reported in the literature.

\section{Disadvantages}

In the eyes of the students the three main disadvantages of combining research and teaching in the person of the academic are:

- Availability is sometimes problematic (Lindsay, Breen, and Jenkins 2002). Academics are both researchers and teachers, which means that they have to divide their time and attention between both activities. In a questionnaire study by Healey et al. (2010), this was the aspect reported most often (15\% of the students) in response to the question regarding what students saw as having a negative impact on their learning.

- Academics' research sometimes takes priority over teaching (Healey et al. 2010, Lindsay, Breen, and Jenkins 2002). Many academics value research more than teaching, or assume that good subject matter knowledge is a substitute for good teaching. 
- The interest of academics might lead to a limited curriculum (Lindsay, Breen, and Jenkins 2002), or a disproportionate attention paid to teachers' favourite topics, at the expense of course goals (Neumann 1994) or the students' interests (Lindsay, Breen, and Jenkins 2002).

Another aspect mentioned by students when asked about their experiences with research is that they experience a great distance between themselves as students and the research being done at university (Lindsay, Breen, and Jenkins 2002; Robertson and Blackler 2006; Zamorski 2002). Robertson and Blackler (2006) indicate that this may depend on the discipline: physics undergraduates have less sense of belonging to a research community than geography and English undergraduates. Zamorski (2002) reports that students perceive both an underestimation (for instance, students who would like to participate in research, but are considered 'not good enough') and an overestimation (for instance, writing a thesis with little support and preparation) of their research ability.

\section{Advantages}

However, students report far more advantages than disadvantages regarding academics' involvements with research (Healey et al. 2010; Turner, Wuetherick, and Healey 2008). These perceived advantages can be summarised as:

- Teachers' enthusiasm for their research, and henceforth for the subject matter, enhances students' motivation (Healey et al. 2010; Jenkins et al. 1998). Students enjoy their classes more and are fascinated by activities related to, or the outcomes of, their teacher's research (Robertson and Blackler 2006).

- Students see classes taught by teachers who are also active researchers as more intellectually stimulating and challenging. This is especially the case if the students are given research assignments, as these are considered different and more challenging than other tasks (Neumann 1994; Robertson and Blackler 2006).

- Students perceive an increased understanding of and interest in the subject, and an improvement of their own research skills when they are taught or supervised by active researchers (Turner, Wuetherick, and Healey 2008).

- Students value their teacher's expertise (Neumann 1994). This not only refers to the 'reflected glory of being taught by well-known researchers' (Healey et al. 2010), but also raises the credibility of the teacher and hence of the subject matter being taught (Jenkins et al. 1998). Students especially appreciate accurate and up-to-date knowledge, which they think these experts provide (Robertson and Blackler 2006). Other characteristics that are attributed are a competence in supervising project work (Jenkins et al. 1998), using relevant examples (Neumann 1994), and pointing to useful research methods (Neumann 1994), all because of the teacher's own experience in research projects.

- The students also appreciate their 'critical questioning approach' and research findings. Both are thought to enhance students' academic disposition (Neumann 1994). This teaches students that research is never finished, and that there is much to be learned by the academic community as a whole too (Turner, Wuetherick, and Healey 2008). 


\section{Research aim}

In most of these studies the focus has been either on the teacher perspective or on the student perception, so that it is only partly possible to see relations between the research involvement in teaching and the students' experiences. If we are to better understand the advantages or disadvantages of specific ways of linking research and teaching, there is a need for studies in which attention is paid to both sides: the learning environment that is created, and more precisely the way in which research is incorporated, and the way students experience this (Neumann 1996). In this project we have brought both sides together in looking in detail at courses from both the teacher and the student perspective. Hence, we were able to relate certain characteristics of the learning environment as intended and implemented to the learning outcomes and student experiences, i.e. the attained learning environment (van den Akker 2003). Thus, this research aimed to describe how academics intentionally use research in their teaching, and what learning outcomes from these learning environments their students perceive.

\section{Method}

\section{Sample}

Twelve academics in the Faculty of Humanities at Leiden University were willing to participate in this research project. This group consisted of academics with a background in all the main disciplines in the faculty, namely (art) history, linguistics and cultural studies. The group included academics whose field of study was the western world as well as those focusing on the non-western world. Four of them were women and eight men, with ages ranging from 31 to 59, and positions ranging from assistant professor to full professor.

\section{Procedure}

All participants were asked to spend one term fostering a stronger link between research and teaching in one of their courses in the way they thought to be most fruitful. In this way we explicitly did not want to prescribe any direction, but wanted the teachers to design their course in a way closest to their view of strengthening the research-teaching nexus. The courses ranged from first-year (bachelor's) courses to courses in the master's programme. Data were gathered from both the teachers and the students. All activities and data sources for this research project are presented in Figure 1 in chronological order. In the project we measured both academics' beliefs about the research-teaching nexus (before the start and at the end of the term) and teachers' and students' perceptions. As we wanted to ensure a multifaceted understanding, we included both primary data sources and additional data sources in the design of this research project. We will first describe the primary data sources for both the teacher perspective and the student perspective, before turning to the additional sources.

\section{Teacher perspective}

From the teachers we collected course goals, course programmes and weekly logs. Before the start of the term all teachers were asked to provide course goals, in which 




Figure 1. Overview of the research project.

they explained clearly what they wanted the students to achieve during the course. Furthermore, the teachers were asked to hand in a course programme in which they provided information on the content of each session, on what the students were supposed to do in preparation for that class, and how examination would take place. During the course the teachers kept a weekly log (Clark, and Peterson 1986), in which they reflected on the last class (i.e. the implemented curriculum) and looked forward to the next class. Their reflection on the last session was based on the following questions: What did you want to achieve? What was the result? In what way did you strengthen the link between research and teaching? What was characteristic for this class? What do you think the students learned? Their preview of the next session was supported by the following questions: What do you want to achieve? How do you plan to achieve this? In what way will you strengthen the link between research and teaching? What is the rationale behind this?

\section{Student perspective}

In order to get to the student perspective (i.e. the perceived curriculum), we conducted interviews with groups of the students of each teacher. These group interviews were conducted at the end of the course. The groups consisted of one to six students, depending on the total number of students. The interviews consisted of four parts. The first part focused on the students' backgrounds. In the second part the students were asked individually what the two most important things were that they learned during the course: this was then reported and discussed by all participating students. In this part of the interview the students were not made aware of the teacher's goals. The third part concerned their opinion on whether the goals formulated by their teacher 
had been achieved. The fourth part questioned in what way the students had noticed that their teacher was also an active researcher.

\section{Additional sources}

Several additional sources were deployed to improve interpretation. Regarding the teacher perspective this included interviews and class visits. Next to the use of Q-sorts to investigate academics' beliefs about the research-teaching nexus, both course goals and course programme were discussed during an interview at the start of the term; these represented the intended curriculum and were intended to ensure a better understanding of the two primary data sources by the researcher. Class visits were also conducted; these were additional as we preferred to rely on detailed descriptions in the weekly logs to learn what happened in each class during the whole course. Since the number of students was rather small in most courses, frequent class visits would be a considerable intrusion into the established learning environment. However, we did visit most courses once, to improve our understanding of what the teachers wrote in their weekly logs.

Regarding the student perspective, we also administered a questionnaire in which all students were asked to report on the research intensiveness of their course (van der Rijst et al. 2009). These data were less precise and were, therefore, used to verify the results of the group interviews, to see whether there were any discrepancies between the results of the interviews with only a few students and the questionnaire involving the whole group.

\section{Analysis}

The analysis consisted of three phases. First, the course was characterised based on the information provided by the teacher. Second, the responses of the students were analysed, and finally the results of these two steps were related to each other.

\section{Teacher perspective}

In an earlier study (Visser-Wijnveen et al. 2010) we developed a code book to characterise various forms of integrating research and teaching based on interview data of 30 academics. This code book formed the basis for the current study, consisting of three main themes: orientation, approach and curriculum. The theme 'orientation' was used to categorise the teachers' course goals, and is concerned with what the academics aim at in teaching, such as academic disposition or academic knowledge. The course programmes and weekly logs were coded using the categories and codes in the 'approach' and 'curriculum' themes. We first coded the course programme, as this provided us with an overview of the whole course. Next, we coded the weekly logs to obtain a detailed description of what happened during the classes, and to note any contingent deviations from the original course programme. The theme 'approach' regards the way in which research and teaching are integrated, and was used to code the activities that were carried out by teachers and students, such as literature reading or individual research projects. The content of the course was characterised using the theme 'curriculum', distinguishing between disciplinary research or the teacher's own research. An overview of the code book is given in Table 1. 
Table 1. Overview of code book.

\begin{tabular}{|c|c|c|c|c|}
\hline \multirow[b]{2}{*}{ Theme } & \multicolumn{2}{|c|}{ Teacher perspective } & \multicolumn{2}{|c|}{ Student perspective } \\
\hline & Category & Code & Code & Theme \\
\hline \multirow[t]{4}{*}{ Orientation } & \multirow[t]{4}{*}{ Towards teaching } & Academic disposition & Disposition & $\begin{array}{l}\text { Learning } \\
\quad \text { outcomes }\end{array}$ \\
\hline & & Divulge research & $\begin{array}{l}\text { Research } \\
\quad \text { awareness }\end{array}$ & \\
\hline & & Train researcher & Skills & \\
\hline & & Academic knowledge & Knowledge & \\
\hline \multirow[t]{10}{*}{ Approach } & \multirow[t]{2}{*}{ Learning about research } & Lecturing & & \\
\hline & & Literature reading & & \\
\hline & \multirow[t]{4}{*}{ Inquiry learning } & Analysis & & \\
\hline & & Assignments & & \\
\hline & & Discussions & & \\
\hline & & Reporting & & \\
\hline & \multirow[t]{2}{*}{ Simulation } & Group research project & & \\
\hline & & $\begin{array}{l}\text { Individual research } \\
\text { project }\end{array}$ & & \\
\hline & \multirow[t]{2}{*}{ Participation } & Teacher's own research & & \\
\hline & & Academic world & & \\
\hline \multirow[t]{8}{*}{ Curriculum } & \multirow[t]{5}{*}{ Disciplinary research } & Current research & & \\
\hline & & Research content & & \\
\hline & & Research process & & \\
\hline & & Student research & & \\
\hline & & The researcher & & \\
\hline & \multirow[t]{3}{*}{ Teacher's own research } & Current research & & \\
\hline & & Research content & & \\
\hline & & Research process & & \\
\hline
\end{tabular}

\section{Student perspective}

The heart of our analysis was the interview fragments in which students mentioned what they thought were the two most important learning outcomes. This part of the interview consisted of their initial reactions on this topic. These answers were considered most reliable as the students had not yet been made aware of their teacher's specific course goals. To be able to relate the reported learning outcomes to the goals set by the teachers, all learning outcomes were coded according their equivalents in the 'orientation' theme: see Table 1.

\section{Relationship between course and learning outcomes}

Finally, all these elements were combined to construct an overview of every course. The courses were then compared, and grouped on the basis of the characteristics of these courses (teacher perspective), in order to be able to describe the relation between certain features in the course and student learning and experience. 


\section{Results}

\section{Characterisation of courses}

The courses taught by the academics reflected five ways of linking research and teaching. We will first characterise the course types before we turn to the question of student learning. Table 2 shows descriptive details of all courses, using fictitious names in order to preserve the anonymity of the participants.

\section{A. Using the teacher's own research to illustrate the subject matter}

Two first- or second-year courses were included that focused on the basics of the disciplines in question. The teachers' goals were teaching basic knowledge, and in one of the courses basic research skills, namely to 'analyse and translate poems' (goals Philip). The approach consisted of mainly lecturing about the subject matter during classes, with students preparing assignments beforehand, which were discussed during class. Regarding research, the focus was on the results, both of research in general, referring to research of other academics in the field, as well as the teacher's own research; for example, 'we discussed the pronunciation of the various language variants. I told them about my own research into the languages of Central Asia' (log - Paula). Teachers paid some attention to their own research process and the problems they encountered while doing research, usually as an illustration of the content.

\section{B. Focusing on the researcher's disposition and position}

Two other courses focused on fostering an academic disposition in the students. These teachers wanted the students to better understand the discipline, but the most important object was to teach students to be critical, and to independently take and defend their position in a debate. Alexandra states in her goals: 'the student develops into an independent academic researcher, who is able to ask critical questions, to conduct research, and to present and defend research results clearly'. In this approach literature reading had an important place, next to class discussions, during which again specific attention was paid to aspects of an academic disposition. An example from Charles's

Table 2. Course descriptives.

\begin{tabular}{llllr}
\hline Type & Teacher & Area & Year & Students \\
\hline A & Paula & Cultural studies - Non-western & BA 1 & 10 \\
A & Philip & Cultural studies - Non-western & BA 2 & 7 \\
B & Alexandra & Art History - Western & BA 3 & 48 \\
B & Charles & History - Non-western & MA & 6 \\
C & Richard & Linguistics - Western & BA 3 & 2 \\
C & Sophia & Linguistics - Non-western & BA 3 & 11 \\
C & Harold & History - Non-western & BA 3 & 10 \\
D & Henry & History - Western & BA 3 & 12 \\
D & Diana & Linguistics - Western & MA & 8 \\
D & Eric & Cultural studies - Non-western & BA 3 & 3 \\
E & Ian & Linguistics - Non-western & BA 3/MA & 2 \\
E & Edward & Linguistics - Non-western & MA & 2 \\
\hline
\end{tabular}


course programme is: 'I expect you to read up on the theme and to come with at least one relevant topic and research question for next week', followed by a specification of the literature. Furthermore, students were asked to write a paper based on secondary literature in the field. During class explicit attention was paid to the position of the researcher; this was considered an important part of linking research and teaching.

\section{Introducing students to literature, after which students conduct research projects}

Three courses can be characterised as having a double focus: on knowledge or disposition, and on research skills; for example, 'to be able to summarise and evaluate an article critically, and to be able to conduct a simple research project' (goals Richard). The first part of these courses consisted of classes about the relevant subject matter, while the last part focused on the students' own research projects, used as simulations of how research is conducted. Sophia summarised her course programme as follows: 'The first five classes consist of the explanation and discussion of important texts, and afterwards the students have to conduct their own research project'. Close attention was paid to research methods in the field. Because of the twofold design of the course the focus was first on the disciplinary research process, using the teacher's own research subject as a framework, and in the second half the attention switched to the themes and topics of the students' research projects. Harold described this switch in his log: 'we will continue the discussion on both provocative articles, and then start with the first presentations'.

\section{Follow in the teacher's footsteps}

The approach in these three courses has much in common with the courses in category $\mathrm{C}$, but here the teacher's own research plays a more central role. For example, the theme of Eric's course was closely related to his own research and an upcoming international conference. The teachers want their students to become independent researchers, and therefore they provide them with an environment in which they follow in the footsteps of their teacher. This might include coming along to a conference after thorough preparation, commenting on a book chapter written by the teacher, or reproducing the teacher's own research step by step. Diana wrote as a clarification to her course programme: 'this is the programme the students get on their first class, the rest of the programme will follow (to make sure that they are not influenced by knowledge that a researcher lacks at the start)'. All students were introduced to the relevant literature, and conducted their own research project related to their teacher's research. The focus was on their teacher's ongoing research, by which the students were introduced to research results as well as processes. Henry wrote in his log: 'I distributed a scheme with the way I normally plan my own research. I used it as basic principle for the course planning'.

\section{E. Participation in the teacher's research}

Two graduate courses were designed as participation in research. A small number of interested students joined the researcher in analysing new research material. Edward explains in his course programme: 'During the meetings we critically discuss the texts that are in advance translated by the students ... The course is embedded in a current research project of the teacher'. The teachers wanted the students to become 
independent researchers and, in showing them how they themselves analysed the materials, they were able to serve as role models for their students. The students' input was highly valued. Furthermore, the teachers aimed at introducing the students further to the discipline, so that they would know all important 'rules' of the field. For example, Ian's students 'need to be aware of, and be able to apply arguments for dating anonymous historic texts' (goals). The emphasis was solely on the teachers' ongoing research and especially on the research process, as this was considered the key to arrive at valuable research results.

\section{Student learning}

\section{A. Using the teacher's own research to illustrate the subject matter}

The teachers focused on academic knowledge and training students to become researchers, using the example of their own research. The students reported learning outcomes related to these goals. One of Philip's students, whose course was on ancient poetry, explained, 'If I needed to give two main lines I would on the one hand emphasise the analytical aspects, such as metre and style figures, and on the other hand literature as a mirror of the society and culture' (skills and knowledge). One of his fellow students added: 'It is not just the poem itself, but also the background ... you get an idea of how society was at that time, what was going on in their heads' (knowledge). In this way they referred to both the main research skills, i.e. analysing, and to knowledge acquisition, i.e. ancient society and poetry.

\section{B. Focusing on the researcher's disposition and position}

The teachers here focused primarily on academic disposition, with the use of class discussions. The students in both groups reported that they learned to think critically, such as 'critical thinking, not to be satisfied too soon' (disposition). However, one of them said that this was not new to her, as it was a favourite topic of their teacher. In addition to this, Alexandra's students became aware of the importance of checking notes and sources: 'Always check the notes, many times you might even learn more from the notes than from the text itself', and 'regarding the texts in the textbook, where do they come from, who wrote them', 'and when' (disposition) added another student. Furthermore, students learned some practical skills such as where to find what literature, and got an idea about who were the important authors in the field (knowledge).

\section{Introducing students to literature, after which students conduct research projects}

In this group the teachers focused primarily on research skills, with disposition or knowledge coming second; they followed a twofold approach combining theory and research assignments. All students reported that they learned how to (better) conduct research, such as 'I also learned how to do research, as we saw many different ways of doing research. Furthermore, how to interpret your data, for example using statistics' (skills). Harold's students emphasised that they learned more about doing a larger research project than in earlier years. This included finding more detailed answers to research questions, and giving an overview of the topic itself. Related to this were dispositional aspects; as one student explained, 'Normally, you are taught this is the truth, but in this course it was quite clear that is the opposite, it [knowledge] is not finished yet' (disposition). 


\section{Follow in the teacher's footsteps}

The teachers here focused primarily on research skills, and to a lesser extent on knowledge, by showing what doing research meant for them. Their students all reported research awareness, and some of them also skills and knowledge. The teacher's research was an important cue for awareness. Diana's students discovered that their teacher also needed to rethink her research several times, and that this is normal in research: 'During her research she had many hypotheses which did not hold after testing. Or that she needed to change tracks, she was very honest about it, how that worked' (research awareness). Henry's students reported various outcomes, next to research awareness, on knowledge: 'I learned a lot more about the period, because of the literature I read for my research project', and on research skills: 'Heuristics. How to search for and order information'.

\section{E. Participation in the teacher's research}

The teachers in this category wanted the students to gain research skills and knowledge by participating in their own research. The students reported that the classes were very practical and that they learned to do the researcher's 'handwork', such as 'preparing a critical edition of a manuscript. Starting with a manuscript and ending with a critical edition and all steps in between' (skills). For Edward's students this was neatly interwoven with acquiring critical thinking, and for Ian's student to broaden his outlook. Furthermore, research awareness was manifest in the importance Edward's students attributed to 'the discussion between text and a translation'. According to them the classes were a very good preparation for potential careers as researchers.

\section{Relation between course characteristics and reported learning outcomes}

Table 3 summarises course characteristics and perceived learning outcomes. In the table we only present characteristics that applied to all courses in the specific type, therefore individual differences are not included. Only three of the learning outcomes reported had been explicitly aimed at by the teachers. The aim 'divulge research', which focuses on teaching students what it means to do research, was not mentioned by any of the teachers, while it was an important learning outcome for the students in course type D. Furthermore, the students in types B and C report on 'disposition', which was only aimed at by the teachers in type B. The learning outcome 'knowledge' was reported by several students: however, only in type A did all students mention this among their two main learning outcomes.

\section{Discussion}

\section{The relation between a research-intensive learning environment and student learning}

Our aim was to relate the characteristics of courses in which research and teaching were linked to perceived student learning. Five different ways of integrating research and teaching were found: (A) using one's own research to illustrate the subject matter, (B) focusing on the researcher's disposition and position, (C) introducing students to literature, after which students conduct research projects, (D) follow in the teacher's footsteps, and (E) participation in the teacher's research. In most courses some form of inquiry learning took place, either by teams or individually. None of the courses 
Table 3. Overview of course characteristics and student learning.

\begin{tabular}{|c|c|c|c|c|}
\hline \multirow[b]{2}{*}{ Type } & \multicolumn{3}{|c|}{ Course } & \multirow[b]{2}{*}{ Student learning } \\
\hline & Orientation & Approach & Curriculum & \\
\hline A & $\begin{array}{l}\text { Academic knowledge } \\
\& \text { train researcher }\end{array}$ & $\begin{array}{l}\text { Lecturing \& } \\
\quad \text { assignments }\end{array}$ & Research content & $\begin{array}{l}\text { Knowledge \& } \\
\text { skills }\end{array}$ \\
\hline $\mathrm{B}$ & Academic disposition & $\begin{array}{l}\text { Literature reading, } \\
\text { discussions \& } \\
\text { reporting }\end{array}$ & $\begin{array}{l}\text { Disciplinary } \\
\quad \text { research process }\end{array}$ & Disposition \\
\hline $\mathrm{C}$ & Train researcher & $\begin{array}{l}\text { Literature reading, } \\
\text { discussions \& } \\
\text { individual } \\
\text { research projects }\end{array}$ & $\begin{array}{l}\text { Disciplinary } \\
\text { research process } \\
\& \text { teacher's } \\
\text { research content }\end{array}$ & $\begin{array}{l}\text { Skills \& } \\
\quad \text { disposition }\end{array}$ \\
\hline $\mathrm{D}$ & $\begin{array}{l}\text { Train researcher \& } \\
\text { academic knowledge }\end{array}$ & $\begin{array}{l}\text { Literature reading, } \\
\text { discussions \& } \\
\text { individual } \\
\text { research projects }\end{array}$ & $\begin{array}{l}\text { Teacher's current } \\
\text { research }\end{array}$ & $\begin{array}{l}\text { Skills \& research } \\
\text { awareness }\end{array}$ \\
\hline E & $\begin{array}{l}\text { Train researcher \& } \\
\quad \text { academic knowledge }\end{array}$ & $\begin{array}{l}\text { Participation in } \\
\text { teacher's research }\end{array}$ & $\begin{array}{l}\text { Teacher's current } \\
\text { research process }\end{array}$ & Skills \\
\hline
\end{tabular}

focused solely on research methods. Furthermore, class size in type E, in which participation was realised, was far smaller than in most other courses, although class sizes were generally small due to discipline and level. Only type A was concerned with first- and second-year students, which definitely influenced the way in which research and teaching were linked. However, in the third and fourth years there still was a variety of ways in which both were linked.

The students reported more learning outcomes related to disposition and awareness than would be expected judging from the teachers' goals. Only a few of the teachers formulated goals on disposition and awareness, yet this is contrary to the literature on linking research and teaching, because the dispositional aspects are considered to be the main benefits of the research-teaching nexus (Elen and Verburgh 2008). The students in courses in which the teaching was closely related to the teacher's own research reported research awareness. This means that these students learned what research is about, and what it really takes to conduct research. Some students explicitly referred to their teacher as an example of somebody conducting 'real research', and how this changed their view on what research implies. Acquiring an academic disposition was mainly equated with learning critical thinking. The students learned to apply this critical thinking in their individual projects, and were stimulated by discussing their ability to analyse critically with their teacher. Hence, our small-scale study indicates that an academic disposition is best learned if students have to apply this in any kind of research assignment, which should also include feedback on their performance, and that awareness of what research entails is best served by a close look at the teacher's own research.

\section{Methodological considerations}

This study was characterised by the collection of a variety of data, and therefore can be considered a mixed-method approach. Triangulation (Meijer, Verloop, and Beijaard 
2002) was established by data source (teacher perspective and students' perspective), method (individual interviews, group interviews, written materials, additional class visits and questionnaire) and data type (mostly qualitative; one additional source was quantitative). The different sources proved to be supplementary to each other, and revealed different aspects of the learning environment and student experience. The intended curriculum was best measured by the course programme and the course goals, providing information on what the teachers intended to do during the course and to what end. The interpretation of the written sources was simplified by the oral elucidation the teachers gave. These sources provide the bigger picture for the courses. The implemented curriculum was measured by the weekly logs. These provided detailed information on the various classes as perceived by the teachers. So, both types of sources not only provided information on the intended and implemented level (van den Akker 2003), but, more importantly, provided an overview and a refined image. It appeared necessary to interpret the various sources in the light of the others. The weekly logs, especially, could only be interpreted knowing the teacher's intentions for the course, as they usually described what happened on a very detailed level without referring to the general picture. For example, the weekly logs often refer to student presentations, while the course aim was not in the first place to improve students' presenting skills, but to provide feedback on the students' progress in their research projects. In many cases these projects were not mentioned at all in the weekly logs, while they were an important part of the design of the particular course, as explained in the course goals and programmes. So this study has shown the strength of combining a set of different data sources.

\section{Conclusion}

In conclusion, we can state that it is worthwhile and important to look in detail at research-intensive learning environments in which students take part. This reveals interesting relations between learning environments and perceived learning outcomes. Our study revealed some unexpected benefits arising from specific ways of bringing students into contact with research, as the attained learning environment yielded more outcomes than originally intended by the teacher. It is important in this respect to see that students reported more learning outcomes on the dispositional level than intended by their teachers, although many studies consider this to be the main aim of linking research and teaching (Elen, Lindblom-Ylänne, and Clement 2007; Elen and Verburgh 2008; McLean and Barker 2004; van der Rijst 2009). Further study might provide insight into potential hesitance of teachers to explicitly formulate dispositional goals. Furthermore, students reported learning on the level of awareness, which was not included in the teachers' course goals at all, and only partly discussed by earlier studies (Robertson and Blackler 2006; Turner, Wuetherick, and Healey 2008).

Our study indicates a relation between the development of an academic disposition and courses in which students were stimulated to put this disposition into practice in research assignments. Feedback on students' performance when putting the disposition into practice proved to be helpful. This might be a specific interpretation of the valued difference of intellectually challenging and disposition-influencing assignments of research-active teachers, as compared to those of other teachers reported by students in earlier studies (Neumann 1994; Robertson and Blackler 2006).

Another relation we found was the link between awareness of research and an encounter with the teacher's research. In course types D and E the students valued the 
opportunity to get acquainted with their teacher's research, and developed an awareness of research. For teachers of larger classes, who are willing to stimulate students' awareness of research, approach D might be fruitful, as approach E was conducted only with a small number (cf. Shore, Pinker, and Bates 1990) of intrinsically motivated students (cf. Breen and Lindsay 1999). It seems that a less integrated way, i.e. not participating in teacher's research (E), but a guided introduction involving 'real research' (D), proved as least as helpful for students in this respect. This might be due to these teachers designing learning environments which were primarily focused on the students' learning, including a strong introduction to 'real research', while courses in which students participate in research risk focusing too much on the research aspect than on students' learning. So, awareness of research can be enhanced when students get the opportunity to observe closely what teachers do when researching.

\section{References}

Badley, G. 2002. A really useful link between teaching and research. Teaching in Higher Education 7, no. 4: 443-55.

Boyer Commission. 1998. Reinventing undergraduate education: A blueprint for America's research universities. San Francisco: Jossey-Bass..

Breen, R., and R. Lindsay. 1999. Academic research and student motivation. Studies in Higher Education 24, no. 1: 75-93.

Clark, C.M., and P.P. Peterson. 1986. Teachers' thought processes. In Handbook of research on teaching, ed. M.E. Wittrock, 3rd ed., 255-96. New York: Macmillan.

Coate, K., R. Barnett, and G. Williams. 2001. Relationships between teaching and research in higher education in England. Higher Education Quarterly 55, no. 2: 158-74.

Colbeck, C. 1998. Merging in a seamless blend - how faculty integrate teaching and research. Journal of Higher Education 69, no. 6: 647-71.

Durning, B., and A. Jenkins. 2005. Teaching/research relations in departments: The perspectives of built environment academics. Studies in Higher Education 30, no. 4: 407-26.

Elen, J., S. Lindblom-Ylänne, and M. Clement. 2007. Faculty development in researchintensive universities: The role of academics' conceptions on the relationship between research and teaching. International Journal for Academic Development 12, no. 2: 123-39.

Elen, J., and A. Verburgh. 2008. Bologna in European research universities. Implications for bachelor and master programs. Antwerp: Garant.

Healey, M., F. Jordan, B. Pell, and C. Short. 2010. The research-teaching nexus: A case study of students' awareness, experiences and perceptions of research. Innovations in Education and Teaching International 47, no. 2: 235-46.

Jenkins, A., T. Blackman, R. Lindsay, and R. Paton-Saltzberg. 1998. Teaching and research: Student perspectives and policy implications. Studies in Higher Education 23, no. 2: 127-41.

Jenkins, A., R. Breen, R. Lindsay, and A. Brew. 2003. Reshaping teaching in higher education, linking teaching with research. London: Kogan Page.

Lindsay, R., R. Breen, and A. Jenkins. 2002. Academic research and teaching quality: The views of undergraduate and postgraduate students. Studies in Higher Education 27, no. 3 : 309-27.

McLean, M., and H. Barker. 2004. Students making progress and the 'research-teaching nexus' debate. Teaching in Higher Education 9, no. 4: 407-19.

Meijer, P.C., N. Verloop, and D. Beijaard. 2002. Multi-method triangulation in a qualitative study on teachers' practical knowledge: An attempt to increase internal validity. Quality \& Quantity 36, no. 2: 145-67.

Neumann, R. 1992. Perceptions of the teaching-research nexus - A framework for analysis. Higher Education 23, no. 2: 159-71.

Neumann, R. 1994. The teaching-research nexus: Applying a framework to university students' learning experiences. European Journal of Education 29, no. 3: 323-38.

Neumann, R. 1996. Researching the teaching-research nexus: A critical review. Australian Journal of Education 40, no. 1: 5-18. 
Robertson, J., and G. Blackler. 2006. Students' experiences of learning in a research environment. Higher Education Research and Development 25, no. 3: 215-29.

Robertson, J., and C. Bond. 2001. Experiences of the relation between teaching and research: What do academics value? Higher Education Research and Development 20, no. 1: 5-19.

Shore, B.M., S. Pinker, and M. Bates. 1990. Research as a model for university teaching. Higher Education 19, no. 1: 21-35.

Smeby, J.-C. 1998. Knowledge production and knowledge transmission. The interaction between research and teaching at universities. Teaching in Higher Education 3, no. 1: 5-20.

Turner, N., B. Wuetherick, and M. Healey. 2008. International perspectives on student awareness, experiences and perceptions of research: Implications for academic developers in implementing research-based teaching and learning. International Journal for Academic Development 13, no. 3: 199-211.

Van den Akker, J.J.H. 2003. Curriculum perspectives: An introduction. In Curriculum landscapes and trends, ed. J.J.H. van den Akker, W. Kuiper, and U. Hameyer. Dordrecht: Kluwer.

Van der Rijst, R.M. 2009. The research-teaching nexus in the sciences: Scientific research dispositions and teaching practice. Dissertation, Leiden University.

Van der Rijst, R.M., G.J. Visser-Wijnveen, T. Verstelle, and J.H. van Driel. 2009. Studentbeleving van de onderzoeksintensiviteit van universitaire onderwijsomgevingen [Student experience of the research intensiveness of learning environments at university]. Pedagogische Studiën 86, no. 3: 214-29.

Visser-Wijnveen, G.J., J.H. van Driel, R.M. van der Rijst, N. Verloop, and A. Visser. 2010. The ideal research-teaching nexus in the eyes of academics - Building different profiles. Higher Education Research and Development 29, no. 2: 195-210.

Zamorski, B. 2002. Research-led teaching and learning: A case. Teaching in Higher Education 7, no. 4: 411-27.

Zubrick, A., I. Reid, and P. Rossiter. 2001. Strengthening the nexus between teaching and research. Canberra: Department of Education, Training and Youth Affairs. 